\title{
Groundwater quality assessment using the water quality pollution indices in Toyserkan Plain
}

\author{
Soheil Sobhanardakani ${ }^{1}$, Lobat Taghavi ${ }^{2}$, Behzad Shahmoradi ${ }^{3}$, Amin Jahangard ${ }^{4}$ \\ ${ }^{1}$ Associate Professor, Department of the Environment, College of Basic Sciences, Hamedan Branch, Islamic Azad University, Hamedan, \\ Iran \\ ${ }^{2}$ Assistant Professor, Department of the Environmental Pollution, College of Environment and Energy, Science and Research Branch, \\ Islamic Azad University, Tehran, Iran \\ ${ }^{3}$ Assistant Professor, Kurdistan Environmental Health Research Center, Kurdistan University of Medical Sciences, Sanandaj, Iran \\ ${ }^{4}$ MSc, Young Researchers \& Elite Club, Hamedan Branch, Islamic Azad University, Hamedan, Iran
}

\begin{abstract}
Background: Iran is located within the dry and semi dry regions, thus almost $90 \%$ of the required water is secured via the use of groundwater. Owing to the increasing pollution of water resources, this study was performed to evaluate water quality pollution indices for heavy metals ( $\mathrm{As}, \mathrm{Zn}, \mathrm{Pb}$ and $\mathrm{Cu}$ ) contamination monitoring in Toyserkan Plain during spring and summer in 2012.

Methods: A total of 20 ground water wells were chosen randomly. The samples were filtered $(0.45 \mu \mathrm{m})$ and kept cool in polyethylene bottles. Samples were taken for the analysis of metals, the former was acidified with $\mathrm{HNO}_{3}$ to $\mathrm{pH}$ lower than 2. Metal concentrations were determined using ICP-OES.

Results: The results revealed that the mean values of contamination index $\left(\mathrm{C}_{\mathrm{d}}\right)$, heavy metal pollution index (HPI) and heavy metal evaluation index (HEI) in samples for spring season were -2.81, 9.74 and 1.20, respectively and were $-2.67,9.51$ and 1.32 , respectively in samples for summer season and this indicates low contamination levels. Comparing the mean concentrations of the evaluated metals with WHO permissible limits demonstrated a significant difference $(P<0.05)$. Thus, the mean concentrations of the metals were significantly lower than the permissible limits.

Conclusion: Although the heavy metal pollution of the ground water in Toyserkan Plain is not higher than permissible limits, the irregular and long-term utilization of agricultural inputs, use of wastewater and sewage sludge in agriculture, over utilization of organic fertilizers and establishment of pollutant industries can threaten the ground water, and cause irreversible damages in this area.

Keywords: Heavy metals, Groundwater, Water quality pollution indices, Toyserkan Plain

Citation: Sobhanardakani S, Taghavi L, Shahmoradi B, Jahangard A. Groundwater quality assessment using the water quality pollution indices in Toyserkan Plain. Environmental Health Engineering and Management Journal 2017; 4(1): 21-27. doi: 10.15171/EHEM.2017.04.
\end{abstract}

Article History:

Received: 13 August 2016

Accepted: 1 November 2016

ePublished: 14 November 2016

*Correspondence to:

Soheil Sobhanardakani Email: s_sobhan@iauh.ac.ir

\section{Introduction}

Urbanization, industrialization, agriculture and exploitation of natural resources, are basic activities associated with living in contemporary societies that imposed pollutant loads especially toxic metals into natural cycles like soil, water and air cycles $(1,2)$. Nowadays, globally, heavy metals have been taken into consideration owing to their toxicity, ability to accumulate in the biota and adverse health effects even at low concentrations (3-5). One of the most important properties of heavy metals, which differentiate them from other toxic pollutants, is that they are not easily biodegradable in the environment $(2,6)$. Apart from the potential toxicity of heavy metals to living organisms, these pollutants are stable in the environment and tend to accumulate in the tissues of plants and animals (7). Water cycle due to the dynamism and its constant nature is more exposed to pollution when compared to the soil and atmosphere cycles (5). Water resources are very important for mankind existence and economical development. People around the globe have utilized groundwater as a source of drinking water, and even today more than $50 \%$ the world's population depends on groundwater for survival $(8,9)$. So, the contamination of these resources by heavy metals is a serious ecological problem.

Metals like $\mathrm{Cu}, \mathrm{Fe}$ and $\mathrm{Zn}$, are essential metals since they play important roles in biological systems, while $\mathrm{As}, \mathrm{Hg}$ and $\mathrm{Pb}$ are toxic, even in trace amounts $(10,11)$. It should be noted that the essential metals can also produce toxic effects at high concentrations $(11,12)$.

Arsenic is a widely distributed metalloid, occurring in the biosphere. The combustion of fossil fuel for production of energy and smelting of non-ferrous metals are two significant processes that lead to the contamination of the environment, especially the source of atmospheric pollution 
for this element. Other sources of As are arsenical pesticides, chemicals such as chromated copper arsenate used for the manufacturing of wood preservatives (13).

Zinc is an essential structural and functional element in biological systems which often catalyzes reactions, binds to substrates by favoring various reactions via the mediation of redox or oxidation-reduction reactions, through reversible changes in the oxidation state of the metal ions. Of course, $\mathrm{Zn}$ harms some physiological activities such as breathing and causes other diseases $(14,15)$.

Lead may damage the kidney and cause symptoms of chronic toxicity, such as poor reproductive capacity, impaired organ function, tumors, blood pressure and hepatic abnormalities (16). In addition, $\mathrm{Pb}$ can also affect brain activity by interfering with neurotransmitter release and synapse formation. Exposure to $\mathrm{Pb}$ via the accidental ingestion of $\mathrm{Pb}$ paint, inhalation of traffic exhaust fumes and the consumption of $\mathrm{Pb}$-contaminated food can cause the reduction of IQ, learning disabilities, hyperactivity, slow growth, impaired hearing and antisocial behaviors (17-19).

Copper is one of the most abundant trace elements with vitamin-like impact in human body and living systems and is found in a wide range of foods eaten by humans such as nuts, many fruits and vegetables, red meat, shellfish, and in many vitamin supplements. Despite the small amount of $\mathrm{Cu}$ (50-120 mg) found in the human body, it plays a crucial role in different kinds of biochemical processes (20). Copper which is an essential micronutrient for growing plants should be supplied via organic and artificial fertilizers for healthy hormone secretion, nerve conduction, and the growth of bones and connective tissue. A constant diet of $\mathrm{Cu}$, even at entirely allowable limits, can break down the barrier that keeps undesirable toxins from entering the brain, and an increase in the production of beta-amyloid. On the other hand, critical doses of $\mathrm{Cu}$ can cause inflammation in the brain tissues, anorexia, fatigue, hair loss, acne, allergies, depression, premenstrual syndrome, migraines, anxiety, childhood hyperactivity, panic attacks, kidney and liver dysfunction, strokes elevated cholesterol, adrenal hyperactivity and insufficiency, learning disorders, autism and cancer (21).

Quality indices employ a series of reproducible judgments to compile the effects of all the pollution parameters and are a useful and relatively easy method to evaluate the composite influence of overall pollution (22). For heavy metal contamination assessment in water resources, several methods were developed. The Contamination index, the Heavy metal potential index and the heavy metal evaluation index (HEI) are pollution indices which help in assessing the present level of pollution (23).

Iran is located within the dry and semi dry regions, thus almost $90 \%$ of the required water is secured via the use of groundwater (24). Owing to the geological structure of Toyserkan township especially minerals containing As, $\mathrm{Zn}, \mathrm{Pb}$, and $\mathrm{Cu}$ (25), and also rapid agricultural growth in Toyserkan Plain, discharge of heavy and toxic metals into groundwater resources of this region via overutilization of agricultural inputs like chemical and organic fertilizers especially phosphorus fertilizers, zinc sulfate and metalcontaining pesticides are on the increase. Therefore, this study was conducted for the assessment of water quality pollution indices for heavy metals (As, $\mathrm{Zn}, \mathrm{Pb}$ and $\mathrm{Cu}$ ) contamination monitoring in Toyserkan Plain during spring and summer in 2012.

\section{Methods}

Study area

The study was carried out in Toyserkan township in Hamedan province which is located in the western part of Iran. The area of Toyserkan Plain is $792 \mathrm{~km}^{2}$. Drinking water for residents of the Toyserkan township is supplied from 1243 wells, 400 springs and 220 aqueducts (25).

Sampling and sample analysis

In this study, based on the Cochran's sample size formula, groundwater samples were collected from 20 wells with depth of 10 to $90 \mathrm{~m}$ and discharge on the range of 1 to $6 \mathrm{~L} / \mathrm{s}$ basis of different land use pattern, including agricultural and residential areas from open and tube wells to assess the heavy metal contamination during spring and summer seasons in 2012. Figure 1 illustrates the sampling stations in the study area. The samples were collected in acid washed $200 \mathrm{~mL}$ polyethylene bottles to prevent unpredictable changes in characteristic as per standard procedures (26). The collected samples were filtered (Whatman no. 42), preserved with $6 \mathrm{~N} \mathrm{HNO}_{3}$ (Suprapur Merck, Germany) and kept at a temperature of $4^{\circ} \mathrm{C}$ for further analysis $(26,27)$. Concentrations of heavy metals (As, Zn, $\mathrm{Pb}$ and $\mathrm{Cu}$ ) in water samples were determined employing ICP-OES (Varian, 710-ES, Australia).

\section{Valuation methods}

Three documented methods evaluated in this study are the contamination index $\left(\mathrm{C}_{\mathrm{d}}\right)$, heavy metal pollution index (HPI) and HEI developed or proposed by Backman et al, Prasad and Bose, and Edet and Offiong, respectively (27-29).

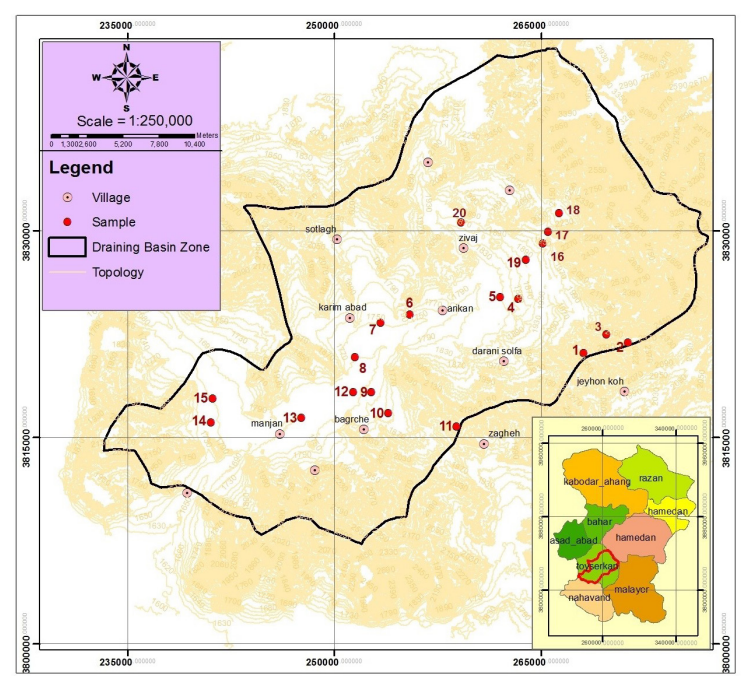

Figure 1. Map of sampling stations. 
The contamination index

In this method, the quality of water is evaluated by the calculation of the degree of contamination. The $\mathrm{C}_{\mathrm{d}}$ is computed separately for each sample of water analyzed, as a sum of the contamination factors of individual components exceeding the upper permissible value. Hence, the $\mathrm{C}_{\mathrm{d}}$ summarizes the combined effects of several quality parameters considered harmful to household water. The contamination index is calculated from Equations 1 and 2:

$$
C d=\sum_{i=1}^{n} C_{f i}
$$

where

$$
C_{f i}=\frac{C A_{i}}{C N_{i}}-1
$$

$\mathrm{C}_{\mathrm{fi}}$ indicates contamination factor for the ith component, $\mathrm{C}_{\mathrm{Ai}}$ indicates analytical value for the $i$ th component, $\mathrm{C}_{\mathrm{Ni}}$ indicates upper permissible concentration of the $i$ th component ( $\mathrm{N}$ denotes the 'normative value') $(2,27)$.

The resultant $C_{d}$ value identifies areas of varying contamination levels which are grouped into three categories as follows: $\mathrm{C}_{\mathrm{d}}<1$ (low), $\mathrm{C}_{\mathrm{d}}=1-3$ (medium) and $\mathrm{C}_{\mathrm{d}}>3$ (high) $(5,27)$.

The upper permissible concentration value $\left(\mathrm{C}_{\mathrm{Ni}}\right)$ was taken as the maximum admissible concentration (MAC).

\section{Heavy metal pollution index}

The HPI represents the total water quality with respect to heavy metals and based on weighted arithmetic quality mean method. The HPI is developed in two steps. The first is by establishing a rating scale for each selected parameter giving weightage and second is by selecting the pollution parameter on which the index is to be based. The rating system is an arbitrarily value between 0 to 1 and its selection depends on the importance of individual quality considerations in a comparative way or it can be evaluated by making values inversely proportional to the recommended standard for the corresponding parameter $(2,27,30,31)$. In computing the HPI, Prasad and Bose (29) considered unit weightage as a value inversely proportional to the recommended standard $\left(\mathrm{S}_{\mathrm{i}}\right)$ of the corresponding parameter as proposed by Reddy (32).

The HPI model is presented in Equation 3 (31):

$$
H P I=\frac{\sum_{i=1}^{n} W_{i} Q_{i}}{\sum_{i=1}^{n} W_{i}}
$$

where $\mathrm{Q}_{\mathrm{i}}=$ the sub-index of the $i$ th parameter, $\mathrm{W}_{\mathrm{i}}=$ the unit weightage of the $i$ th parameter and $n=$ the number of parameters considered. The sub-index of the parameter is calculated by Equation 4:

$$
Q_{i}=\sum_{i=1}^{n} \frac{\left\{M_{i}(-) I_{i}\right\}}{\left(S_{i}-I_{i}\right)}
$$

where $\mathrm{M}_{\mathrm{i}}$ indicates the monitored value of heavy metal of $i$ th parameter, $\mathrm{I}_{\mathrm{i}}$ indicates the ideal value of the $i$ th parameter and $\mathrm{S}_{\mathrm{i}}$ indicates the standard value of the $i$ th parameter. The sign (-) indicates numerical difference of the two values, ignoring the algebraic sign. Low heavy metal pollution (HPI < 100), heavy metal pollution on the threshold risk $(H P I=100)$ and high heavy metal pollution (critical pollution index) (HPI > 100). If the samples have HPI values greater than 100, water is not potable $(2,27,29,31)$.

In computing the HPI for the present study, $\mathrm{As}, \mathrm{Zn}, \mathrm{Pb}$ and $\mathrm{Cu}$ were utilized. The weightage $\left(\mathrm{W}_{\mathrm{i}}\right)$ was taken as the inverse of MAC, $S_{i}$ the World Health Organization (WHO) standard for drinking water and $\mathrm{I}_{\mathrm{i}}$ the guide value for the chosen element (Table 1).

Heavy metal evaluation index

HEI focuses on heavy metals in water samples for estimating the water quality (33). The water quality index is classified into three categories which include HEI $<400$ (low heavy metals), $400<\mathrm{HEI}<800$ (moderate to heavy metals) and HEI $>800$ (high heavy metals). The index is calculated from Equation 5 (5):

$$
H E I=\sum_{i=1}^{n} \frac{H_{c}}{H_{\text {mac }}}
$$

where $\mathrm{H}_{\mathrm{c}}$ is the monitored value of the $i$ th parameter and $\mathrm{H}_{\text {mac }}$ the MAC of the ith parameter $(27,33)$.

\section{Results}

The results of the heavy metal concentrations in ground water samples for spring and summer seasons are given in Tables 2 and 3. Also the correlation matrix between elements for spring and summer seasons are presented in Table 4.

The results indicate that $\mathrm{As}, \mathrm{Zn}, \mathrm{Pb}$ and $\mathrm{Cu}$ concentrations in groundwater samples collected from Toyserkan Plain in spring season ranged from 0.08 to $7.48,0.12$ to $15.64,0.09$ to 5.50 and 0.89 to $13.58 \mu \mathrm{g} / \mathrm{L}$, respectively.

The results indicate that $\mathrm{As}, \mathrm{Zn}, \mathrm{Pb}$ and $\mathrm{Cu}$ concentrations in groundwater samples collected from Toyserkan Plain in summer season ranged from 0.57 to $7.21,0.41$ to 16.42 , 0.19 to 4.46 and 6.54 to $15.76 \mu \mathrm{g} / \mathrm{L}$, respectively.

Correlation at $5 \%$ level of significance $(P>0.05)$ demonstrated no significant correlation between the following pairs: $\mathrm{As}$ and $\mathrm{Zn}, \mathrm{Pb}, \mathrm{Cu} ; \mathrm{Zn}$ and $\mathrm{Pb}$; $\mathrm{Cu}$ and $\mathrm{Pb}$ and $\mathrm{Cu}$ in water samples for spring and summer seasons.

The computed $\mathrm{C}_{\mathrm{d}}$, HPI and HEI values for each location, correlation between index values and concentration of metal and correlation between different indices values for spring and summer seasons are given in Tables 5 to 7, respectively.

The computed $\mathrm{C}_{\mathrm{d}}$ demonstrates that the mean values in

Table 1. Standard used for the indices computation (27)

\begin{tabular}{ccccc}
\hline & w & s & I & MAC \\
\hline As & 0.02 & 50 & 10 & 50 \\
$\mathrm{Zn}$ & 0.0002 & 5000 & 3000 & 5000 \\
$\mathrm{~Pb}$ & 0.70 & 100 & 10 & 1.50 \\
$\mathrm{Cu}$ & 0.001 & 1000 & 2000 & 1000 \\
\hline
\end{tabular}

Abbreviations: W; weightage (1/MAC); S, standard permissible in ppb; I, highest permissible in ppb; MAC, maximum admissible concentration/ upper permissible. 
Table 2. Concentration of $\mathrm{As}, \mathrm{Zn}, \mathrm{Pb}$ and $\mathrm{Cu}\left(\mu \mathrm{g} \mathrm{L}^{-1}\right)$ in groundwater samples collected from Toyserkan Plain in spring season

\begin{tabular}{|c|c|c|c|c|}
\hline Station & As & $\mathrm{Zn}$ & $\mathrm{Pb}$ & $\mathrm{Cu}$ \\
\hline 1 & 7.48 & 3.75 & 1.13 & 7.78 \\
\hline 2 & 4.20 & 1.80 & 0.10 & 8.49 \\
\hline 3 & 6.21 & 10.27 & 0.09 & 7.22 \\
\hline 4 & 0.40 & 2.57 & 1.61 & 0.89 \\
\hline 5 & 3.28 & 6.05 & 1.06 & 6.67 \\
\hline 6 & 2.06 & 3.41 & 0.17 & 9.93 \\
\hline 7 & 5.62 & 7.42 & 4.38 & 13.58 \\
\hline 8 & 1.79 & 15.64 & 1.70 & 11.51 \\
\hline 9 & 6.44 & 11.20 & 5.50 & 9.16 \\
\hline 10 & 3.56 & 3.61 & 1.12 & 10.44 \\
\hline 11 & 4.62 & 1.62 & 1.25 & 9.08 \\
\hline 12 & 0.08 & 1.05 & 1.27 & 10.34 \\
\hline 13 & 7.04 & 0.40 & 0.31 & 10.25 \\
\hline 14 & 0.35 & 0.17 & 3.96 & 11.83 \\
\hline 15 & 1.18 & 1.17 & 2.43 & 11.86 \\
\hline 16 & 3.81 & 1.05 & 2.37 & 12.06 \\
\hline 17 & 2.96 & 0.12 & 0.52 & 5.57 \\
\hline 18 & 3.50 & 0.29 & 2.80 & 5.83 \\
\hline 19 & 3.78 & 3.20 & 1.10 & 5.80 \\
\hline 20 & 5.20 & 2.14 & 0.42 & 3.56 \\
\hline Mean & $3.68 \pm 2.24$ & $4.24 \pm 3.85$ & $1.66 \pm 1.51$ & $8.59 \pm 3.19$ \\
\hline
\end{tabular}

Table 3. Concentration of $\mathrm{As}, \mathrm{Zn}, \mathrm{Pb}$ and $\mathrm{Cu}(\mu \mathrm{g} / \mathrm{L})$ in groundwater samples collected from Toyserkan Plain in summer season

\begin{tabular}{lcccc}
\hline Station & As & Zn & Pb & Cu \\
\hline 1 & 0.57 & 4.75 & 1.55 & 12.60 \\
2 & 3.23 & 8.55 & 2.39 & 6.54 \\
3 & 5.06 & 8.83 & 1.39 & 13.14 \\
4 & 5.83 & 3.23 & 1.78 & 11.65 \\
5 & 3.45 & 11.07 & 1.78 & 11.13 \\
6 & 7.08 & 4.18 & 0.46 & 11.93 \\
7 & 0.76 & 10.24 & 1.64 & 12.91 \\
8 & 3.91 & 9.08 & 1.05 & 13.25 \\
9 & 7.21 & 16.42 & 1.34 & 12.72 \\
10 & 5.75 & 9.83 & 0.19 & 12.74 \\
11 & 7.11 & 3.73 & 4.46 & 11.42 \\
12 & 3.37 & 0.94 & 3.00 & 15.76 \\
13 & 3.89 & 8.54 & 1.98 & 12.25 \\
14 & 5.26 & 2.66 & 1.98 & 12.72 \\
15 & 2.10 & 3.53 & 2.58 & 12.15 \\
16 & 3.86 & 0.41 & 1.53 & 13.02 \\
17 & 3.23 & 0.87 & 1.43 & 13.39 \\
18 & 3.22 & 1.74 & 1.16 & 13.30 \\
19 & 3.06 & 1.28 & 1.49 & 13.31 \\
20 & 1.86 & 16.03 & 3.74 & 13.83 \\
Mean & $3.99 \pm 1.93$ & $6.30 \pm 4.89$ & $1.85 \pm 1.01$ & $12.49 \pm 1.71$ \\
\hline
\end{tabular}

spring and summer seasons were -2.80 and -2.67 , respectively, and indicate low contamination. The computed HPI shows that the mean values in spring and summer seasons were 9.74 and 9.51, respectively and are lower than 100, the critical value for drinking water for all the locations. Moreover, the computed HEI shows that the mean values in spring and summer seasons were 1.20 and 1.32 , respec- tively and indicate low heavy metal pollution.

A comparison between the indices and heavy metal concentration demonstrates significant correlation with $\mathrm{Pb}$ for spring and summer samples (Table 6). This indicates that $\mathrm{Pb}$ is the main contributory parameter. Moreover, the correlation between $\mathrm{C}_{\mathrm{d}}$, HPI and HEI is significant (Table 7). Therefore, the three existing methods; the Contamination index, the HPI and the HEI provide same results.

\section{Discussion}

In order to assess the groundwater resources of Toyserkan Plain, groundwater samples were collected from 20 wells. Four elements including $\mathrm{As}, \mathrm{Zn}, \mathrm{Pb}$ and $\mathrm{Cu}$ in the samples were measured and used in calculating $C_{d}$, HPI and HEI indices. The results demonstrated that the mean concentration of metals in samples in spring season ( $\mu \mathrm{g}$ $\mathrm{L}^{-1}$ ) were $3.68 \pm 2.24$ for As, $4.24 \pm 3.85$ for $\mathrm{Zn}, 1.66 \pm 1.51$ for $\mathrm{Pb}$ and $8.59 \pm 3.19$ for $\mathrm{Cu}$, respectively (Table 2 ). In addition, the mean concentration of metals in samples in summer season $\left(\mu \mathrm{g} \mathrm{L}^{-1}\right)$ were $3.99 \pm 1.93$ for As, $6.30 \pm 4.89$

Table 4. Correlation matrix between elements

\begin{tabular}{|c|c|c|c|c|}
\hline & As & $\mathrm{Zn}$ & $\mathrm{Pb}$ & $\mathrm{Cu}$ \\
\hline \multicolumn{5}{|c|}{ Spring } \\
\hline As & & 0.219 & -0.380 & -0.009 \\
\hline $\mathrm{Zn}$ & & & 0.230 & 0.163 \\
\hline $\mathrm{Pb}$ & & & & 0.378 \\
\hline \multicolumn{5}{|c|}{ Summer } \\
\hline As & & 0.030 & -0.125 & -0.115 \\
\hline $\mathrm{Zn}$ & & & 0.018 & -0.161 \\
\hline $\mathrm{Pb}$ & & & & -0.061 \\
\hline
\end{tabular}

Table 5. Evaluation indices

\begin{tabular}{|c|c|c|c|c|c|c|}
\hline \multirow{2}{*}{ Station } & \multicolumn{3}{|c|}{ Spring } & \multicolumn{3}{|c|}{ Summer } \\
\hline & $C_{d}$ & HPI & HEI & $C_{d}$ & HPI & HEI \\
\hline 1 & -3.09 & 10.06 & 0.91 & -2.94 & 10.08 & 1.06 \\
\hline 2 & -3.84 & 11.40 & 0.16 & -2.33 & 9.00 & 1.67 \\
\hline 3 & -3.81 & 11.27 & 0.19 & -2.96 & 9.94 & 1.04 \\
\hline 4 & -2.92 & 10.02 & 1.08 & -2.67 & 9.36 & 1.31 \\
\hline 5 & -3.22 & 10.43 & 0.78 & -2.73 & 9.52 & 1.27 \\
\hline 6 & -3.83 & 11.47 & 0.16 & -3.54 & 10.80 & 0.46 \\
\hline 7 & -0.95 & 6.68 & 3.25 & -2.88 & 9.97 & 1.12 \\
\hline 8 & -2.82 & 9.83 & 1.18 & -3.21 & 10.38 & 0.79 \\
\hline 9 & -0.19 & 5.42 & 3.81 & -2.95 & 9.84 & 1.05 \\
\hline 10 & -3.17 & 10.34 & 0.83 & -3.74 & 11.19 & 0.26 \\
\hline 11 & -3.06 & 10.12 & 0.93 & -0.87 & 6.49 & 3.13 \\
\hline 12 & -3.14 & 10.41 & 0.86 & -1.92 & 8.32 & 2.08 \\
\hline 13 & -3.64 & 10.97 & 0.36 & -2.59 & 9.39 & 1.41 \\
\hline 14 & -1.34 & 7.50 & 2.66 & -2.56 & 9.30 & 1.44 \\
\hline 15 & -2.34 & 9.10 & 1.66 & -2.22 & 8.86 & 1.77 \\
\hline 16 & -2.33 & 8.97 & 1.67 & -2.89 & 9.84 & 1.11 \\
\hline 17 & -3.59 & 11.02 & 0.41 & -2.97 & 10.02 & 1.03 \\
\hline 18 & -2.06 & 8.53 & 1.94 & -3.15 & 10.32 & 0.85 \\
\hline 19 & -3.18 & 10.34 & 0.81 & -2.93 & 9.97 & 1.07 \\
\hline 20 & -3.61 & 10.98 & 0.39 & -1.45 & 7.63 & 2.55 \\
\hline Mean & -2.81 & 9.74 & 1.20 & -2.67 & 9.51 & 1.32 \\
\hline
\end{tabular}


Table 6. Correlation between index values and concentration of metals

\begin{tabular}{|c|c|c|c|c|c|c|}
\hline \multirow{2}{*}{ Parameter } & \multicolumn{2}{|c|}{$C_{d}$} & \multicolumn{2}{|c|}{ HPI } & \multicolumn{2}{|c|}{ HEI } \\
\hline & $r$ & $P$ & $r$ & $P$ & $r$ & $P$ \\
\hline & \multicolumn{6}{|c|}{ Spring } \\
\hline As & 0.007 & 0.978 & -0.056 & 0.815 & 0.015 & 0.948 \\
\hline $\mathrm{Zn}$ & 0.240 & 0.308 & -0.250 & 0.287 & 0.244 & 0.299 \\
\hline $\mathrm{Pb}$ & $0.999^{a}$ & 0.000 & $-0.996^{a}$ & 0.000 & $0.998^{a}$ & 0.000 \\
\hline \multirow[t]{2}{*}{$\mathrm{Cu}$} & 0.381 & 0.097 & -0.376 & 0.102 & 0.390 & 0.089 \\
\hline & \multicolumn{6}{|c|}{ Summer } \\
\hline As & -0.067 & 0.779 & -0.003 & 0.990 & -0.068 & 0.777 \\
\hline $\mathrm{Zn}$ & 0.020 & 0.993 & -0.022 & 0.926 & 0.021 & 0.929 \\
\hline $\mathrm{Pb}$ & $0.998^{\mathrm{a}}$ & 0.000 & $-0.991^{a}$ & 0.000 & $0.998^{a}$ & 0.000 \\
\hline $\mathrm{Cu}$ & -0.068 & 0.777 & 0.080 & 0.737 & -0.067 & 0.780 \\
\hline
\end{tabular}

${ }^{a}$ Correlation is significant at the 0.01 level (2-tailed).

Table 7. Correlation between different indices values

\begin{tabular}{lccc}
\hline \multicolumn{1}{c}{$\boldsymbol{r}$} & $\boldsymbol{P}$ \\
\hline $\mathrm{C}_{d}$ vs. HPI & \multicolumn{2}{c}{ Spring } \\
$\mathrm{C}_{d}$ vs. HEI & $-0.999^{\mathrm{a}}$ & 0.000 \\
$\mathrm{HPI}$ vs. HEI & $0.999^{\mathrm{a}}$ & 0.000 \\
\hline \multicolumn{4}{c}{ Summer } \\
\hline $\mathrm{C}_{d}$ vs. HPI & $-0.998^{\mathrm{a}}$ & 0.000 \\
$\mathrm{C}_{d}$ vs. HEI & \multicolumn{3}{c}{0.000} \\
HPI vs. HEI & $-0.997^{\mathrm{a}}$ & 0.000 \\
\hline
\end{tabular}

${ }^{a}$ Correlation is significant at the 0.01 level (2-tailed).

for $\mathrm{Zn}, 1.85 \pm 1.01$ for $\mathrm{Pb}$ and $12.49 \pm 1.71$ for $\mathrm{Cu}$, respectively (Table 3 ). The higher values of metals concentration in summer season compared to spring season may be due to reduced aquifer recharge and reduced dilution of pollutants as a result of increase in water temperature during the summer season.

Based on the results, heavy metal pollution is not observed in any cases. According to Table 5, the values of $\mathrm{C}_{\mathrm{d}}$, HPI and HEI indices were found in the range of -3.84 to $-0.19,5.42$ to 11.47 and 0.16 to 3.81 , respectively, in spring season. The highest values of $\mathrm{C}_{\mathrm{d}}$, HPI and HEI were found in the sample collected from stations number 9,6 and 9, respectively. Furthermore, during summer season, the values of same indices are increased up to -3.74 to -0.87 , 6.49 to 11.19 and 0.26 to 3.13 , respectively. The highest values of $\mathrm{C}_{\mathrm{d}}$, HPI and HEI in this season were found in the sample collected from station number 11, 10 and 11, respectively. The higher values of $C_{d}$, HPI and HEI may be due to agricultural activities during spring and summer seasons. The $\mathrm{C}_{\mathrm{d}}$, HPI and HEI values of the samples within study area are found below the critical pollution index (100), and this indicates that the water is not critically polluted with respect to studied heavy metals and is suitable for drinking.

Nevertheless, the values of these three indices in groundwater collected from Toyserkan Plain are totally below the critical values, but severe precautions such as managing the use of agricultural inputs (chemical fertilizers and metal-containing pesticides), use of wastewater and sewage sludge in agriculture, over utilization of organic fertilizers and establishment of pollutant industries must be taken into consideration in this area. In this regard, Sobhanardakani (34) evaluated water quality pollution indices for groundwater resources of Ghahavand Plain in Hamedan province and reported that mean values of $\mathrm{C}_{\mathrm{d}}$, HPI and HEI in samples for spring 2012 were $-2.27,9.01$ and 1.73, respectively and were $-1.95,8.69$ and 2.04 , respectively in samples for summer 2012 and indicates low contamination levels. Sobhanardakani et al (35) analyzed As, Zn, Pb, $\mathrm{Cd}$ and $\mathrm{Cu}$ content in groundwater resources of Asadabad Plain in Hamedan province in 2012 and reported that the mean values of indices in samples from spring and summer seasons were 25.61 and 27.28, respectively for HPI and were 9.29 and 8.88 , respectively for HEI, and indicates low contamination levels. Nazari and Sobhanardakani (36) analyzed As and $\mathrm{Zn}$ concentrations in groundwater resources of Qaleh Shahin Plain in Kermanshah province and reported that the HPI values in winter 2014 vary between 1.09 to 11.4 (mean 6.11) and vary between 1.83 to 22.8 (mean 8.78) in summer 2014 and are lower than 100, the critical value for drinking water for all the sampling stations. Sobhanardakani and Nazari (37) analyzed Pb and Cd concentrations in groundwater resources of Qaleh Shahin Plain in Kermanshah province and reported that the HPI values in winter 2014 vary between 0.32 to 7.69 (mean 4.73 ) and vary between 8.92 to 13.90 (mean 11.74) in summer 2014 and are lower than 100, the critical value for drinking water for all the sampling stations.

\section{Conclusion}

According to the findings, heavy metal pollution was not observed in any water samples. So, groundwater samples of the Toyserkan Plain have been identified as suitable for drinking but based on the correlation matrix (Table 6), $\mathrm{Pb}$ has a great role in the quality of water samples. This indicates that the water quality indices proved to be a very useful tool in evaluating overall pollution of the ground water resources. Finally, it can be concluded however, that the values of these three indices in groundwater samples collected from Toyserkan Plain are totally below the critical values. Nevertheless, it is recommended that severe precautions should be taken for controlling the sources of 
groundwater pollution in this area.

\section{Acknowledgments}

The authors are grateful to the Hamedan Branch, Islamic Azad University for providing facilities to conduct and complete this study.

\section{Ethical issue}

The authors certify that all data collected during the study is presented in this manuscript, and no data from the study has been or will be published separately.

\section{Competing interests}

The authors declare that they have no competing interests.

\section{Authors' contributions}

All authors participated in the study design, literature search, writing of the manuscript, and data acquisition, analysis, and interpretation. All authors critically reviewed, refined, and approved the manuscript

\section{References}

1. Gribble GW. The natural production of chlorinated compounds. Environ Sci Technol 1994; 28(7): 310A-9A. doi: $10.1021 /$ es00056a712.

2. Nasrabadi T. An index approach to metallic pollution in river waters. Int J Environ Res 2015; 9(1): 385-94.

3. Morillo J, Usero J, Gracia I. Partitioning of metals in sediments from the Odiel River (Spain). Environ Int 2002; 28(4): 263-71. doi: 10.1016/S0160-4120(02)00033-8.

4. Baghvand A, Nasrabadi T, Nabi Bidhendi GR, Vosoogh A, Karbassi AR, Mehrdadi N. Groundwater quality degradation of an aquifer in Iran central desert. Desalination 2010; 260(1-3): 264-75. doi: 10.1016/j.desal.2010.02.038.

5. Hosseinpour Moghaddam M, Lashkaripour GR, Dehghan P. Assessing the effect of heavy metal concentrations (Fe, $\mathrm{Pb}, \mathrm{Zn}, \mathrm{Ni}, \mathrm{Cd}, \mathrm{As}, \mathrm{Cu}, \mathrm{Cr}$ ) on the quality of adjacent groundwater resources of Khorasan steel complex. Int J Plant Anim Environ Sci 2014; 4(2): 511-18.

6. Rauret G, López-Sánchez JF, Sauquillo A, Rubio R, Davidson C, Ure A, et al. Improvement of the BCR three step sequential extraction procedure prior to the certification of new sediment and soil reference materials. J Environ Monit 1999; 1(1): 57-61. doi: 10.1039/a807854h.

7. Bhaskar CV, Kumar K, Nagendrappa G. Assessment of heavy metals in water samples of certain locations situated around Tumkur, Karnataka, India. E-J Chem 2010; 7(2): 349-52. doi: 10.1155/2010/415150.

8. Rajankar PN, Gulhane SR, Tambekar DH, Ramteke DS, Wate SR. Water quality assessment of groundwater resources in Nagpur Region (India) Based on WQI. E-J Chem 2009; 6(3): 905-08. doi: 10.1155/2009/971242.

9. Rizwan R, Gurdeep S, Manish Kumar J. Application of heavy metal pollution index for ground water quality assessment in Angul District of Orassia, India. Int J Res Chem Environ 2011; 1(2): 118-22. doi: 10.1007/s12665-014-3882-5.

10. Sobhanardakani S, Tayebi L, Farmany A, Cheraghi M. Analysis of trace elements $(\mathrm{Cu}, \mathrm{Cd}$ and $\mathrm{Zn})$ in muscle, gill and liver tissues of some fish species using anodic stripping voltammetry. Environ Monit Assess 2012; 184(11): 660711. doi: 10.1007/s10661-011-2445-4.
11. Hosseini SV, Aflaki F, Sobhanardakani S, Tayebi L, Babakhani Lashkan A, Regenstein JM. Analysis of mercury, selenium and tin concentrations in canned fish marketed in Iran. Environ Monit Assess 2013; 185(8): 6407-12. doi: 10.1007/s10661-012-3033-y.

12. Carvalho ML, Santiago S, Nunes ML. Assessment of the essential element and heavy metal content of edible fish muscle. Anal Bioanal Chem 2005; 382(2): 426-32. doi: 10.1007/s00216-004-3005-3.

13. Järup L. Hazards of heavy metal contamination. Br Med Bull 2003; 68(1): 167-82. doi: 10.1093/bmb/ldg032.

14. Tahsin N, Yankov B. Research on accumulation of zinc (Zn) and cadmium (Cd) in sunflower oil. Journal of Tekirdag Agricultural Faculty 2007; 4(1): 109-12.

15. Sobhanardakani S, Jamshidi K. Assessment of metals (Co, $\mathrm{Ni}$, and $\mathrm{Zn}$ ) content in the sediments of Mighan Wetland using geo-accumulation index. Iranian Journal of Toxicology 2015; 9(30): 1386-90.

16. Abou-Arab AAK, Ayesh AM, Amra HA, Naguib K. Characteristic levels of some pesticides and heavy metals in imported fish. Food Chem 1996; 57(4): 487-92. doi: 10.1016/S0308-8146(96)00040-4.

17. Dahiya S, Karpe R, Hegde AG, Sharma RM. Lead, cadmium and nickel in chocolate and candies from suburban areas of Mumbai. India. J Food Comp Anal 2005; 18 (6): 517-22. doi: org/10.1016/j.jfca.2004.05.002.

18. Hosseini SV, Sobhanardakani S, Tahergorabi R, Delfieh P. Selected heavy metals analysis of Persian sturgeon's (Acipenser persicus) caviar from Southern Caspian Sea. Biol Trace Elem Res 2013; 154(3): 357-62. doi: 10.1007/s12011013-9740-6.

19. Adekunle IM, Akinyemi MF. Lead levels of certain consumer products in Nigeria: a case study of smoked fish foods from Abeokuta. Food Chem Toxicol 2004; 42(9): 1463-8. doi: 10.1016/j.fct.2004.04.007.

20. Saracoglu S, Tuzen M, Soylak M. Evaluation of trace element contents of dried apricot samples from Turkey. J Hazard Mater 2009; 167(1-3): 647-52. doi: org/10.1016/j. jhazmat.2009.01.011.

21. Ackah M, Anim AK, Zakaria N, Osei J, Saah-Nyarko E, Gyamfi ET, et al. Determination of some heavy metal levels in soft drinks on the Ghanaian market using atomic absorption spectrometry method. Environ Monit Assess 2014; 186(12): 8499-507. doi: 10.1007/s10661-014-4019-8.

22. Prasad B, Sangita K. Hevay metal pollution index of ground water of an abandoned open cast mine filled with fly Ash: a case study. Mine Water and the Environment 2008; 27(4): 265-7. doi: 10.1007/s10230-008-0050-8.

23. Maria-Alexandra H, Roman C, Ristoiu D, Popita G, Tanaselia C. Assessing of water quality pollution Indices for hevay metal contamination. A study case from Medias City groundwaters. Agricultura 2013; 87(3-4): 25-31. doi: 10.15835/arspa.v87i3-4.9974.

24. Sobhanardakani S, Jamali M, Maànijou M. Evaluation of As, $\mathrm{Zn}, \mathrm{Cr}$ and $\mathrm{Mn}$ concentrations in groundwater resources of Razan Plain and preparing the zoning map using GIS. Journal of Environmental Science and Technology 2014; 16(2): 25-38.

25. Sobhanardakani $S$, Talebiani $S$, Maànijou M. Evaluation of $\mathrm{As}, \mathrm{Zn}, \mathrm{Pb}$ and $\mathrm{Cu}$ concentrations in groundwater resources of Toyserkan Plain and preparing the zoning map using GIS. J Mazandaran Univ Med Sci 2014; 24(114): 120-9. [In Persian]. 
26. American Public Health Association (APHA). Standard Methods for Examination of Water and Waste water. 20th ed. Washington DC: APHA; 2005.

27. Edet $\mathrm{AE}$, Offiong OE. Evaluation of water quality pollution indices for heavy metal contamination monitoring. A study case from Akpabuyo-Odukpani area, Lower Cross River Basin (southeastern Nigeria). Geo J 2002; 57(4): 295-304. doi: 10.1023/B:GEJO.0000007250.92458.de

28. Backman B, Bodis D, Lahermo P, Rapant S, Tarvainen T. Application of a groundwater contamination index in Finland and Slovakia. Environ Geol 1998; 36(1-2): 55-64. doi: $10.1007 / \mathrm{s} 002540050320$.

29. Prasad B, Bose JM. Evaluation of the heavy metal pollution index for surface and spring water near a Limeston mining area of the lower Himalayas. Environ Geol 2001; 41(1-2): 183-8. doi: 10.1007/s002540100380.

30. Horton RK. An index systems for rating water quality. J Water Pollut Contr Federat 1965; 37(3): 300-6.

31. Mohan SV, Nithila P, Reddy SJ. Estimation of heavy metals in drinking water and development of heavy metal pollution index. J Environ Sci Health A 1996; 31(2): 283-9. doi: $10.1080 / 10934529609376357$.

32. Trivedy RK. Encyclopedia of Environmental Pollution and
Control (vol 2). Karad, India: Environmental Media; 1995. p. 342 .

33. Edet AE, Merkel BJ, Offiong OE. Trace element hydrochemical assessment of the Calabar Coastal Plain Aquifer, southeastern Nigeria using statistical methods. Environ Geol 2003; 44(2): 137-49. doi: 10.1007/s00254002-0738-1.

34. Sobhanardakani S. Evaluation of the water quality pollution indices for groundwater resources of Ghahavand Plain, Hamedan Province, western Iran. Iran J Toxicol 2016; 10(3): $35-40$.

35. Sobhanardakani S, Yari AR, Taghavi L, Tayebi L. Water quality pollution indices to assess the heavy metal contamination, case study: Groundwater resources of Asadabad Plain in 2012. Arch Hyg Sci 2016; 5(4): 221-8.

36. Nazari S, Sobhanardakani S. Assessment of pollution index of heavy metals in groundwater resources of Qaleh Shahin plain (2013-2014). J Kermanshah Univ Med Sci 2015; 19(2): 102-8. [In Persian].

37. Sobhanardakani S, Nazari S. Assessment of $\mathrm{Pb}$ and $\mathrm{Cd}$ pollution in groundwater resources of Qaleeh Shahin Plain using heavy metal pollution index in 2014. Journal of Health System Research 2016; 12(3): 300-6. [In Persian]. 